\title{
THE PREVALENCE OF SIDE-EFFECTS: CIPROFLOXACIN 500 MG SINGLE DOSE PRO- PHYLAXIS AGAINST NEISSERIA MENINGITIDIS OUTBREAK IN POTCHEFSTROOM DURING JULY 2003
}

\section{Michelle Viljoen}

M Sc (Pharmacology)

Senior Lecturer, Department of Pharmacology, School of Pharmacy, North-West University, Potchefstroom Campus Corresponding author: fklmv@puknet.ac.za

\author{
Martie S Lubbe \\ D Pharm \\ Senior Lecturer, Department of Pharmacy Practice, School of Pharmacy, North-West University, Potchefstroom \\ Campus
}

\section{Rina (CL) Meyer}

M Sc (Pharmacology)

Senior Lecturer, Department of Pharmacology, School of Pharmacy, North-West University, Potchefstroom Campus

Keywords: Neisseria meningitidis, ciprofloxacin; single dose; side effects; prophylactic.

\begin{abstract}
Potchefstroom experienced an outbreak of Neisseria meningitidis (N. meningitidis) during May-July 2003. An opportunity for obtaining valuable data arose when mass prophylactic treatment to approximately $28 \%$ of the Potchefstroom community was provided by the Department of Health, North-West Province. The aim of this study was to investigate the prevalence of side-effects experienced by staff and students of the Potchefstroom University for Christian Higher Education (PU for CHE) who received a single prophylactic dose of oral ciprofloxacin $500 \mathrm{mg}$ between 23 and 29 July 2003. Information gained from the Potchefstroom outbreak may be valuable for the future management of similar outbreaks in other communities. Various stakeholders have published related reports, protocols, recommendations and guidelines, which mostly focused on the prevention, management and control of meningococcal disease. Very little has been reported about the side-effects experienced, especially in cases where ciprofloxacin $500 \mathrm{mg}$ single dose had been dispensed. One or more side-effects were reported by $24.2 \%$ of the participants, while $5.4 \%$ had to consult with a health care worker due to the severity of side-effects resulting from a single dose. Practical significance could not be demonstrated for any of the side-effects reported after single versus multiple doses nor when the effects of gender or requirement for medical consultation were tested.
\end{abstract}

\section{OPSOMMING}

'n Uitbraak van Neisseria meningitidis (N. meningitidis) gedurende Mei-Julie 2003 en die daaropvolgende verskaffing van massa-profilakse deur die Departement van Gesondheid, Noordwesprovinsie aan ongeveer $28 \%$ van die plaaslike gemeenskap het ' $n$ geleentheid geskep om waardevolle inligting in te win. Die doel van die studie was om die voorkoms van newe-effekte te ondersoek wat deur die personeel en studente van die Potchefstroomse Universiteit vir Christelike Hoër Onderwys ervaar is na toediening van 'n enkel profilaktiese dosis van siprofloksasien 500 mg tussen 23-29 Julie 2003. Inligting wat hieruit voortspruit mag waardevol wees tydens toekomstige bestuur van uitbrake in ander gemeenskappe. Verskillende belanghebbendes het verslae, protokolle, aanbevelings en riglyne gepubliseer, wat meestal op die voorkoming, bestuur en beheer van meningokokkale siekte gefokus het. Daar is egter min gerapporteer oor die newe-effekte wat ondervind is veral waar siprofloksasien 500mg enkeldosis toegedien is. Een of meer newe-effekte is deur $24.2 \%$ van die deelnemers ervaar en $5.4 \%$ het dit nodig geag om ' $n$ gesondheidswerker te konsulteer in verband met die newe-effekte wat ervaar is. Geen prakties betekenisvolle 
verskille is aangedui indien die effeksgrootte bereken is vir die newe-effekte getoets tussen die enkeldosis versus die meervoudige dosis nie, selfs ook nie nadat die effek van geslag of konsultasie getoets is nie.

\section{INTRODUCTION}

"Few infections can cause the civil, medical, and social stress that occurs when serious meningococcal disease enters a community" (Apicella, 1995:2).

Meningitis is an inflammation of the meninges (the membranes surrounding the brain and spinal cord). Meningitis can be caused by either bacterial or viral infection. Various bacteria can induce meningitis but the most common causes of the reported cases were N. meningitidis (meningococcus) and Streptococcus pneumoniae (pneumococcus) (Beers \& Burkow, 2003:1). Until recently, Haemophilus influenzae type b was the most common cause of meningitis in children older than one month, but vaccination dramatically reduced the incidence (Beers \& Burkow, 2003:1). Meningococcus is a serious life-threatening condition that requires immediate medical treatment.

$N$. meningitidis causes both sporadic disease and outbreaks all over the world. Various reports, protocols, control measures, guidelines, recommendations and policy strategies have been drafted and implemented in order to control and manage the disease (American Academy of Pediatrics, 2000:1500; Centers for Disease Control and Prevention (CDC), 2000:11; Canada Communicable Disease Report, 1994:1825). These mostly deal with the prevention, management and control of meningococcal disease. Very little was reported in these publications about the medication side-effects, especially in cases where a single dose of ciprofloxacin $500 \mathrm{mg}$ was dispensed.

Since 1991, the frequency of localised outbreaks of $N$. meningitidis in the United States of America (USA) increased, especially among college students and recruits in the military. Students, recruits and other military staff living in crowded conditions experience an increased risk for meningococcal infection. For this reason, a vaccine that is protective against four types (A, C, W-135, Y) of N. meningitidis is given to basic trainees and college freshmen, particularly those who live in dormitories (CDC, 2000:11).

\section{STUDY PURPOSE AND RATIONALE}

The purpose of this study was to investigate the prevalence of side-effects experienced by staff and students of the Potchefstroom University for Christian Higher Education (PU for $\mathrm{CHE}$ ), now the Potchefstroom campus of the North-West University) who received a single prophylactic dose of oral ciprofloxacin $500 \mathrm{mg}$ between 23 and 29 July 2003 . The efficacy of ciprofloxacin chemoprophylaxis is not disputed or questioned, the side-effects are well reported in various recognised pharmacological literature. However, very little was reported about the side-effects experienced in cases where ciprofloxacin $500 \mathrm{mg}$ single dose was administered.

Eight confirmed cases of meningitis were reported in the greater Potchefstroom district from May - 30 July (Joint Task Team: Provincial and Local Health Authorities and PU for CHE, 2003c). Five confirmed cases were of students from different tertiary institutions in the city. Three students died and two were treated and discharged from hospital (Joint Task Team: Provincial and Local Health Authorities and PU for CHE, 2003a). Two of the deceased students were from the PU for CHE and they passed away on 23 July (PU for CHE, 2003) and 27 July 2003 respectively (Joint Task Team: Provincial and Local Health Authorities, World Health Organisation (WHO) and the Potchefstroom University, 2003b).

A joint task team headed by doctor TGK Oosthuizen (Chief Director Health Service Delivery, Department of Health, North-West Province) was formed by 28 July 2004 and a decision was made to dispense mass ciprofloxacin $500 \mathrm{mg}$ tablets on 28 July 2003 between 16:00 and 22:00 to staff and students of all the tertiary institutions in the city (Joint Task Team: Provincial and Local Health Authorities and the PU for CHE, 2003c). The rationale was to attempt a simultaneous mass eradication of the $N$. meningitidis bacteria in the population of possible carriers of these bacteria. 
An opportunity arose to gather data concerning the prevalence of side-effects after a single prophylactic dose of oral ciprofloxacin $500 \mathrm{mg}$ was administered on such a large scale and the focus of this investigation was only on the staff and students of the PU for CHE (Potchefstroom campus) in the time period 23-29 July 2003.

\section{PROPHYLACTIC TREATMENT OF MEN- INGITIS}

Chemoprophylaxis is highly effective in some clinical settings and in others it is totally without value and may be deleterious. The use of antimicrobial compounds to prevent infections remains controversial in several situations (Chambers, 2001:1164). The purpose of chemoprophylaxis is to eradicate nasopharyngeal colonisation by $N$. meningitidis, which prevents the disease in contacts and its transmission to non-immune susceptible people. Chemoprophylaxis is not effective in preventing a disease once invasion of tissue has taken place (Canada Communicable Disease Report, 1994:1826).

A comprehensive report was published by the Canadian Paediatric Society (CPS), Infectious Diseases and Immunization Committee, American Academy of Pediatrics (AAP) and the Committee on Infectious Diseases in 1997, which was reaffirmed in February 2003, in which they addressed meningococcal disease prevention and control strategies for practice-based physicians. In their joint statement they stressed that chemoprophylaxis is indicated for close contacts of all persons with invasive meningococcal disease, whether sporadic, or in a cluster or outbreak. The CPS and the AAP currently recommend antimicrobial chemoprophylaxis for contacts of persons with invasive meningococcal disease, including household members, individuals in childcare centres and nursery schools, and persons directly exposed to oropharyngeal secretions through kissing or sharing of food or beverages during the seven days before the onset of disease in the index case. Prophylaxis is not recommended routinely for medical personnel except for those who have had intimate exposure, such as that which occur with mouth-to-mouth resuscitation, intubation or suctioning. The index case should also receive chemoprophylactic antibiotics before discharge unless treated with ceftriaxone. Because the attack rate of secondary disease after a close con- tact is highest in the few days following the onset of disease in the primary case, the delay in providing antimicrobial chemoprophylaxis must be minimised and, ideally, the prophylaxis should be given within 24 hours of case identification. Suggested chemoprophylaxis regimens include rifampin (rifampicin), ceftriaxone and ciprofloxacin and these are shown in Table 1.

Various health departments (Welsh Medicines Information Centre, 2003:5; Massachusetts Department of Public Health, 1999:7) follow similar guidelines as reflected in Table 1 for chemoprophylaxis but for pregnant women they also include Ceftriaxone $250 \mathrm{mg}$ as a single dose, administered intramuscularly.

The WHO provided chemoprophylactic guidelines similar to those reflected in Table 1, but also included spiramycin or minocycline for five days as alternatives (WHO, 1998:28). Their report did not recommend mass chemoprophylaxis to prevent or control epidemics.

Oral rifampicin had been the drug of choice for chemoprophylaxis in recent decades. Rifampicin is $72 \%$ to $90 \%$ effective in eradicating nasopharyngeal carriage and serious adverse effects with short-term therapy are rare. Urine and stools may be stained orange or red and soft contact lenses may become tinted and therefore warnings would be required. Rifampicin may also interfere with the efficacy of oral contraceptives and is not recommended for use during pregnancy. The impact of rifampicin on the metabolism of other medications such as those for seizure prevention and anticoagulation must also be considered. Ceftriaxone administered as a single intramuscular dose is an alternative to rifampicin and is more than $95 \%$ effective in eradicating carriage. In adults who are not pregnant, a single dose of ciprofloxacin is an effective oral alternative to rifampicin in $90 \%$ to $95 \%$ of cases. Although ciprofloxacin is used in children for chemoprophylaxis of meningitis, it is not currently approved for use in children younger than 18 years and should not be used when safer alternatives are available (CPS, 1997:5; Petri, $2001: 1182$ ). Although sulphonamides were effective in preventing disease for many years, the majority of isolates of $N$. meningitidis of serogroups $B$ and $C$ in the USA as well as group $A$ isolates from other countries are now resistant (Petri, 2001:1172).

\section{CIPROFLOXACIN}


Table 1: Recommended chemoprophylaxis regimens for high-risk contacts and index cases of invasive meningococcal disease

\begin{tabular}{|c|c|c|c|c|}
\hline $\begin{array}{l}\text { Infants, } \\
\text { Children } \\
\text { Adults }\end{array}$ & Dose & Duration & $\begin{array}{l}\text { Efficacy } \\
(\%)\end{array}$ & Cautions \\
\hline \multicolumn{5}{|l|}{ Rifampicin } \\
\hline$<1$ month & $\begin{array}{l}5 \mathrm{mg} / \mathrm{kg} \text { oral every } \\
12 \mathrm{~h}\end{array}$ & 2 days & 7290 & $\begin{array}{l}\text { May interfere with } \\
\text { efficacy of oral } \\
\text { contraceptives, some } \\
\text { seizure prevention and } \\
\text { anticoagulant } \\
\text { medications }\end{array}$ \\
\hline$>1$ month & $\begin{array}{l}10 \mathrm{mg} / \mathrm{kg} \\
\text { (maximum } 600 \mathrm{mg} \text { ) } \\
\text { oral every } 12 \mathrm{~h}, 20 \\
\mathrm{mg} / \mathrm{kg} \text { (maximum } \\
600 \mathrm{mg} \text { ) oral every } \\
24 \mathrm{~h}\end{array}$ & $\begin{array}{l}2 \text { days } \\
4 \text { days }\end{array}$ & & $\begin{array}{l}\text { May stain soft contact } \\
\text { lenses }\end{array}$ \\
\hline \multicolumn{5}{|c|}{ Ceftriaxone } \\
\hline$<12$ years & 125 mg I.M. & Single dose & 97 & $\begin{array}{l}\text { To decrease pain at } \\
\text { injection site, dilute with } \\
1 \% \text { lidocaine }\end{array}$ \\
\hline$>12$ years & 250 mg I.M. & Single dose & & \\
\hline \multicolumn{5}{|c|}{ Ciprofloxacin } \\
\hline 18 years & $500 \mathrm{mg}$ oral & Single dose & 9095 & $\begin{array}{l}\text { Not recommended for } \\
\text { use by children }\end{array}$ \\
\hline
\end{tabular}

Information in Table 1, taken from a joint report of the Canadian Paediatric Society (CPS), Infectious Disease and Immunization Committee, American Academy of Pediatrics (AAP) and the Committee on Infectious Diseases, 1997.

Single dose ciprofloxacin was shown to be effective in eradicating pharyngeal carriage of $N$. meningitidis by Gaunt and Lambert (1988:489) when 2100 navy personnel received single oral doses of ciprofloxacin 500 $\mathrm{mg}$ and 570 of the personnel were swabbed $2-4$ days later. An additional 277 personnel members were followed-up for nine weeks afterwards to determine the elimination rate of the pharyngeal carriage. The overall prevalence of carriage declined from $19 \%$ to less than $1.5 \%$ as a result of the use of ciprofloxacin.

Ciprofloxacin is one of a number of fluorinated 4quinolones and is of great importance therapeutically due to the agent's broad antimicrobial activity. It is effective after oral administration for the treatment of a wide variety of infectious diseases (Petri, 2001:1182).

\section{Side effects of ciprofloxacin}

Fluoroquinolones are generally well-tolerated. The most common adverse reactions involve the gastrointestinal tract (nausea, vomiting and/or abdominal discomfort reported by $3 \%$ to $17 \%$ of the patients). Central nervous system side-effects, predominantly mild headache and dizziness have been reported in $0.9 \%$ to $11 \%$ of patients. Skin rashes, including photosensitivity reactions (sensitivity of the skin to direct sunlight), may occur. Allergic reactions have been described, such as hives (urticaria) and anaphylaxis (Petri, 2001:1182).

Three cases of anaphylactic reactions (a rate of about $1: 1000$, much higher than the $1: 100000$ quoted) were reported in approximately 3200 first-year university stu- 
dents who accepted single dose ciprofloxacin $500 \mathrm{mg}$ as prophylactic treatment (Burke \& Burne, 2000:679).

Side-effects reported by naval training personnel after receiving a single dose of oral ciprofloxacin $500 \mathrm{mg}$ were mild in nature with the exception of one recipient who developed an acute urticarial reaction ten minutes after taking the tablet (Gaunt \& Lambert, 1988:493).

Quinolones and fluoroquinolones cause arthralgias (pain in joints) and joint swelling in children receiving ciprofloxacin and are, for that reason, not recommended for use in pre-pubertal children or pregnant women. Leucopoenia, eosinophilia and mild elevations in serum transaminase rarely occur (Petri, 2001:1182).

Many antibiotics, including ciprofloxacin, can alter the normal bacteria in the colon and encourage overgrowth of bacteria responsible for the development of inflammation of the colon (pseudomembranous colitis), causing fever, abdominal pain, diarrhoea, and sometimes even shock (Petri, 2001:1182).

\section{STUDY METHOD}

\section{Research Design and Setting}

An open non-randomised study was conducted, based on a voluntary and anonymous questionnaire distributed in Afrikaans, English and Setswana (refer to addendum) on 31 July 2003 (three days after mass prophylaxis) to students and staff of the PU for CHE. It was decided to target the maximum possible number of participants by posting the questionnaire electronically on the bulletin board of the PU for CHE. In addition, 3500 printed copies were distributed as follows:

a) to the respective House Committee representatives of all residences on and off campus;

b) to two libraries (left at the entrances of the libraries) on campus; and

c) to various departments to include all the workers employed in the kitchens, gardens and hostels together with possible subcontractor workers at that time.

The questionnaire had to be returned on or before 6 August, 2003.

\section{Study Population}

A total of 9075 single prophylactic doses of ciprofloxacin $500 \mathrm{mg}$ tablets were dispensed to staff and students of the PU for CHE as follows:

a) prior to 28 July 2003 (direct contacts to positively diagnosed cases): 539 single doses;

b) mass issue on 28 July 2003: 8525 single doses;

c) issue on 29 July 2003 (to staff and students not available on 28 July 2003): 11 single doses;

d) 9075 Single doses of ciprofloxacin $500 \mathrm{mg}$ were issued;

e) 1537 individuals (16.9\%) voluntarily completed questionnaires and returned them to the Department of Pharmacology before or on the set due date (Joint Task Team: Provincial and Local Health Authorities and PU for CHE, 2003c).

\section{Validity and Reliability}

The following actions were taken in order to ensure the reliability and validity (face and content) of the questions in the questionnaire:

a) special attention was given to ensure that each question only implied one concept; and

b) different preliminary versions of the questionnaire were drawn up and evaluated by various experts in the field of pharmacology, pharmacy practise and statistics.

An application for approval of the study was submitted to the Ethics Committee of the PU for CHE and to the Department of Health, North-West Province and both approved the study.

\section{Statistical Analysis}

The SAS System for Windows (SAS Institute, 2001) was used to create the database and to analyse the data by calculating certain descriptive and inferential statistics. The descriptive statistics included frequency tables, histograms and percentage expressions. Chisquare tests $\left(\chi^{2}\right)$ were used as inferential statistics to determine whether a difference existed between the side-effects reported by the participants who received only a single dose versus the participants who received multiple dose ciprofloxacin $500 \mathrm{mg}$; single dose versus gender effect, multiple dose versus gender effect and single dose-gender versus consultation required. 
Because the responses were voluntary, the participants were not randomly selected. As a result, the following equation and guidelines were used to interpret the practical significance (the effect size) of the results (Steyn, 2002:11):

$$
w=\sqrt{\frac{\chi^{2}}{n}}
$$

where $\left(\chi^{2}\right)$ is the usual Chi-square statistic for a twoway frequency table and $n=$ number of participants. The guidelines used to interpret the results followed the criteria provided by Cohen (1988:227):

$w=0.1$ small effect (non significant)

$w=0.3$ (medium effect)

$w=0.5$ large effect (significant and of practical importance)

\section{RESULTS AND DISCUSSIONS}

Table 2 indicates that 1537 questionnaires were received from voluntary participants. Table 2 reflects the general demographic details of the participants. Table 4 reflects that $51.4 \%$ (741) of the participant $(\mathrm{N}=1443.94$ missing data) indicated that they took a single dose treatment and $48.6 \%$ (702) indicated that they took more than one dose of ciprofloxacin $500 \mathrm{mg}$ during the time period 25 - 29 July 2003. The female participants represented $65.4 \%$ ( $N=731,10$ missing data) and the male participants represented $34.6 \%$ of the voluntary single dose study population.

The data reflected in Table 3 indicate the frequencies and percentages of all the side-effects reported by the participants (expressed as a percentage of 741 participants) who indicated that they took a single dose of ciprofloxacin $500 \mathrm{mg}$. All the responses of the participants (staff; on-campus students; and off-campus students) were combined and the gender contributions are reflected.

The data in Figure 1 indicate the percentage of sideeffects greater than $1 \%$, as reported by the participants who indicated that they took a single dose of ciprofloxacin $500 \mathrm{mg}$ (expressed as a percentage of 741 participants). These side-effects included headache $(9.3 \%)$, nausea $(8.5 \%)$, sleepiness $(8.0 \%)$, dizziness $(5.9 \%)$, stomach cramps $(4.6 \%)$, listlessness $(3.4 \%)$, trembling (2.2\%), insomnia (1.8\%), diarrhoea (1.4\%), itchiness (1.2\%) and heart palpitations (1.1\%).
Table 4 comprises comparative data with respect to the number of participants who experienced side-effects due to single dose versus multiple doses and the number of participants who consulted a healthcare worker due to the side-effect(s) they experienced. It is indicated that 392 (25.5\%) of the 1537 participants (295 females or $19.2 \%$ and 97 males or $6.3 \%$ ) reported one or more side effects. Of these 392 participants, 179 participants (11.6\%) indicated that they took a single dose and 189 (12.3\%) participants indicated that they took more than one dose of ciprofloxacin (24 (1.6\%) participants did not indicate their dosage).

Of the 1537 participants 78 (5.1\%), 40 on a single dose and 36 on multiple doses, (two did not indicate their dosages) indicated that they had to consult a healthcare worker about the side-effects experienced as a result of taking ciprofloxacin.

The side-effects for which further medical consultation was required after single dose ciprofloxacin $500 \mathrm{mg}$ are shown in Figure 2. These side-effects are also expressed as a percentage of 741 single dose participants, constituting headache $(2.0 \%)$, nausea $(1.9 \%)$, dizziness $(1.8 \%)$, sleepiness $(1.5 \%)$, stomach cramps $(0.9 \%)$, listlessness $(0.7 \%)$, diarrhoea $(0.54 \%)$, trembling $(0.54 \%)$, insomnia $(0.4 \%)$, heart palpitations $(0.4 \%)$, vomiting $(0.3 \%)$, convulsions $(0.3 \%)$, skin rash $(0.3 \%)$, visual disturbances $(0.1 \%)$, joint pains $(0.1 \%)$, redness of skin $(0.1 \%)$, itchiness $(0.1 \%)$, tiredness $(0.1 \%)$, cold and flu symptoms $(0.1 \%)$, neck pain/stiffness $(0.1 \%)$, hypertension $(0.1 \%)$, sore throat $(0.1 \%)$ and fever $(0.1 \%)$. Headache, nausea, dizziness and sleepiness were thus the only side-effects reported with a prevalence of greater than $1 \%$ after administration of a single dose of ciprofloxacin $500 \mathrm{mg}$ for which further medical consultation was required.

The SAS-calculated Chi-square-values $\left(\chi^{2}\right)$ for all the various side-effects due to a single dose, and those due to multiple doses, were used in the effect size equation to establish whether the effects experienced were significant. None of the $w$-values reached significance. The effect of gender was tested on the different side-effects reported with a single dose as well as with the side-effects reported after ingestion of multiple doses. Once again, no significance due to gender differences could be shown for any of the side-effects. The effect size tested to measure the relationship be- 
Table 2: Demographic details of all voluntary participants

\begin{tabular}{|c|c|c|c|c|c|c|}
\hline \multirow{2}{*}{ Female } & Staff & $\begin{array}{l}\text { Off campus } \\
\text { students }\end{array}$ & \multicolumn{2}{|c|}{$\begin{array}{l}\text { Hostel students } \\
\text { (On campus) }\end{array}$} & Others & TOTAL \\
\hline & 104 & 204 & \multicolumn{2}{|c|}{710} & 4 & $1022^{\mathrm{B}}$ \\
\hline Male & 47 & 125 & \multicolumn{2}{|c|}{328} & 2 & $502^{\mathrm{B}}$ \\
\hline TOTAL & 151 & \multicolumn{3}{|l|}{$1380^{B}$} & 6 & 1537 \\
\hline $\begin{array}{l}\text { Average age in years (Std. } \\
\text { Dev.) }\end{array}$ & $\begin{array}{l}42.13 \\
(11.9)\end{array}$ & \multicolumn{3}{|l|}{$19.96(1.75)$} & $\begin{array}{l}34.17 \\
(18.48)\end{array}$ & \\
\hline Pregnant & & & & & & 3 \\
\hline Breast feeding & & & & & & 2 \\
\hline \multicolumn{7}{|l|}{ Medication obtained from: } \\
\hline PUK Campus & \multicolumn{5}{|l|}{1270} & \\
\hline Potchefstroom Hospital & \multicolumn{5}{|l|}{18} & 1288 \\
\hline Municipal clinics & \multicolumn{5}{|l|}{5} & 1293 \\
\hline Retail pharmacies & \multicolumn{5}{|l|}{141} & 1434 \\
\hline Other & \multicolumn{5}{|l|}{77} & $1511^{\mathrm{C}}$ \\
\hline \multicolumn{7}{|l|}{ Details of dose and frequency: } \\
\hline $\begin{array}{l}\text { Single dose prophylactic } \\
\text { treatment }\end{array}$ & $478=$ Female & \multicolumn{2}{|c|}{$253=$ Male } & \multicolumn{2}{|c|}{$10=$ no gender specified } & 741 \\
\hline Multiple prophylactic treatment & $481=$ Female & \multicolumn{2}{|c|}{$218=$ Male } & \multicolumn{2}{|c|}{$3=$ no gender specified } & 702 \\
\hline TOTAL & & & & & & $1443^{D}$ \\
\hline
\end{tabular}

$A=$ The participants indicated as "others" are family members (children and spouses) of staff members who also completed the questionnaire by choice.

$\mathrm{B}=13$ participants indicated that they were students (off-campus and on-campus) but did not indicate their gender.

$\mathrm{C}=26$ participants did not indicate where they received their treatment.

$\mathrm{D}=94$ participants did not reply to this section by indicating whether or not they took a single or multiple dose.

tween the side-effects due to a single dose, gender or causing consultation requirement with a health care worker, also indicated no practical significance. These results are not included, as no significance could be shown.

The information obtained through this questionnaire on possible drug interactions and the effect thereof on greater side-effect prevalence was not included in the scope of this article but the data is available for further statistical analysis.

\section{Limitation of the study}

In order to obtain a reliable response in the shortest possible time following the outbreak and accompanying prophylactic treatment, the design and execution of the study were somewhat complicated by the high level of social fear surrounding the outbreak. As a result, the decision to conduct this investigation was only made after the mass prophylaxis exercise had been completed. Therefore, the opportunity to issue the questionnaire simultaneously with the medication was lost, which could have impacted negatively on the response rate. However, in support of the method used the possibility of perceived side-effects being reported was eliminated.

\section{CONCLUSIONS}

One of the main aims of this study was to investigate the prevalence of side-effects after the administration of a single dose of ciprofloxacin $500 \mathrm{mg}$. It is apparent from the data analysis of the 1537 voluntary partici- 
Table 3: Frequencies and percentages of all the side-effects reported (SINGLE DOSE)

\begin{tabular}{|c|c|c|c|c|c|c|}
\hline \multirow[b]{2}{*}{ SIDE-EFFECT } & \multicolumn{3}{|c|}{ FREQUENCY } & \multicolumn{3}{|c|}{ PERCENTAGE \% } \\
\hline & Female & Male & Total & Female & Male & Total \\
\hline Headache & 52 & 17 & 69 & 7.02 & 2.29 & 9.3 \\
\hline Nausea & 48 & 15 & 63 & 6.48 & 2.02 & 8.5 \\
\hline Sleepiness & 47 & 12 & 59 & 6.34 & 1.62 & 8.0 \\
\hline Dizziness & 36 & 8 & 44 & 4.86 & 1.08 & 5.9 \\
\hline Stomach cramps & 21 & 13 & 34 & 2.83 & 1.75 & 4.6 \\
\hline Listlessness & 17 & 8 & 25 & 2.29 & 1.08 & 3.4 \\
\hline Trembling & 14 & 2 & 16 & 1.89 & 0.27 & 2.2 \\
\hline Insomnia & 9 & 4 & 13 & 1.21 & 0.54 & 1.8 \\
\hline Diarrhoea & 5 & 5 & 10 & 0.67 & 0.67 & 1.4 \\
\hline Itchiness & 7 & 2 & 9 & 0.94 & 0.27 & 1.2 \\
\hline Heart palpitations & 6 & 2 & 8 & 0.81 & 0.27 & 1.1 \\
\hline Vomiting & 5 & 2 & 7 & 0.67 & 0.27 & 0.9 \\
\hline Skin rash & 5 & 1 & 6 & 0.67 & 0.13 & 0.8 \\
\hline Visual disturbances & 4 & 1 & 5 & 0.54 & 0.13 & 0.7 \\
\hline Redness of skin & 5 & 0 & 5 & 0.67 & 0.00 & 0.7 \\
\hline Joint pains & 3 & 1 & 4 & 0.40 & 0.13 & 0.5 \\
\hline Tiredness & 2 & 2 & 4 & 0.27 & 0.27 & 0.5 \\
\hline Thirst & 2 & 1 & 3 & 0.27 & 0.13 & 0.4 \\
\hline Convulsions & 1 & 1 & 2 & 0.13 & 0.13 & 0.3 \\
\hline Cold \& Flu & 2 & 0 & 2 & 0.27 & 0.00 & 0.3 \\
\hline Hot flushes & 1 & 1 & 2 & 0.13 & 0.13 & 0.3 \\
\hline Swollen joints & 1 & 0 & 1 & 0.13 & 0.00 & 0.1 \\
\hline Suffocating & 0 & 1 & 1 & 0.00 & 0.13 & 0.1 \\
\hline Urine discoloration & 0 & 1 & 1 & 0.00 & 0.13 & 0.1 \\
\hline Neck pain & 0 & 1 & 1 & 0.00 & 0.13 & 0.1 \\
\hline Toothache & 0 & 1 & 1 & 0.00 & 0.13 & 0.1 \\
\hline Night sweat & 1 & 0 & 1 & 0.13 & 0.00 & 0.1 \\
\hline Sore dry throat & 0 & 1 & 1 & 0.00 & 0.13 & 0.1 \\
\hline Fever & 0 & 1 & 1 & 0.00 & 0.13 & 0.1 \\
\hline
\end{tabular}

Table 4: Comparative data of side-effects reported or medical consultation required after single dose or multiple dose administration

\begin{tabular}{|l|l|l|l|l|}
\hline & Single Dose & Multiple Dose & Missing data & TOTAL \\
\hline Participants & 741 & 702 & 94 & 1537 \\
\hline Side-effects reported & 179 & 189 & 24 & 392 \\
\hline Medical Consultation & 40 & 36 & 2 & 78 \\
\hline
\end{tabular}




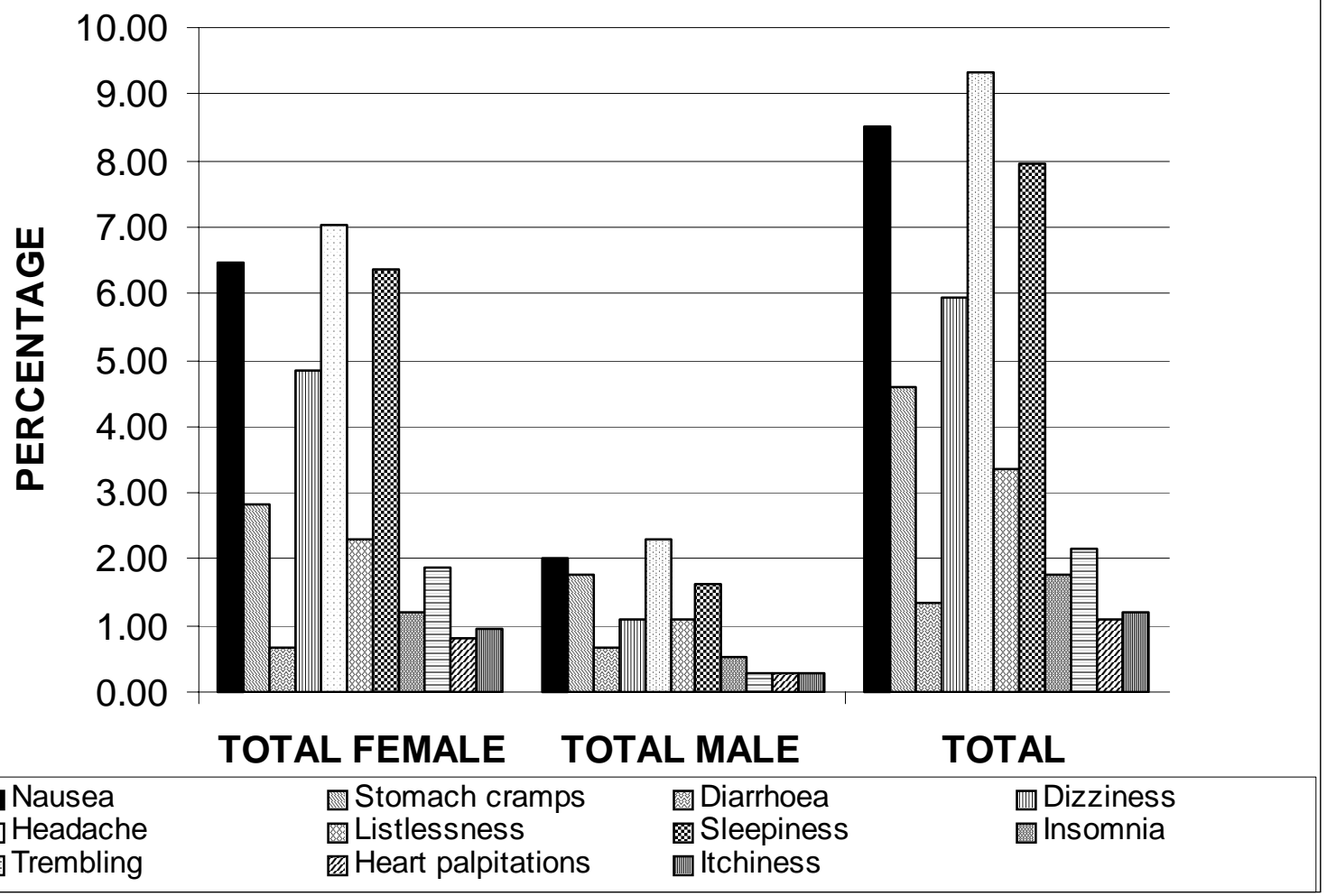

Figure 1: Percentage of total side-effects reported > $1 \%$ (Single Dose)

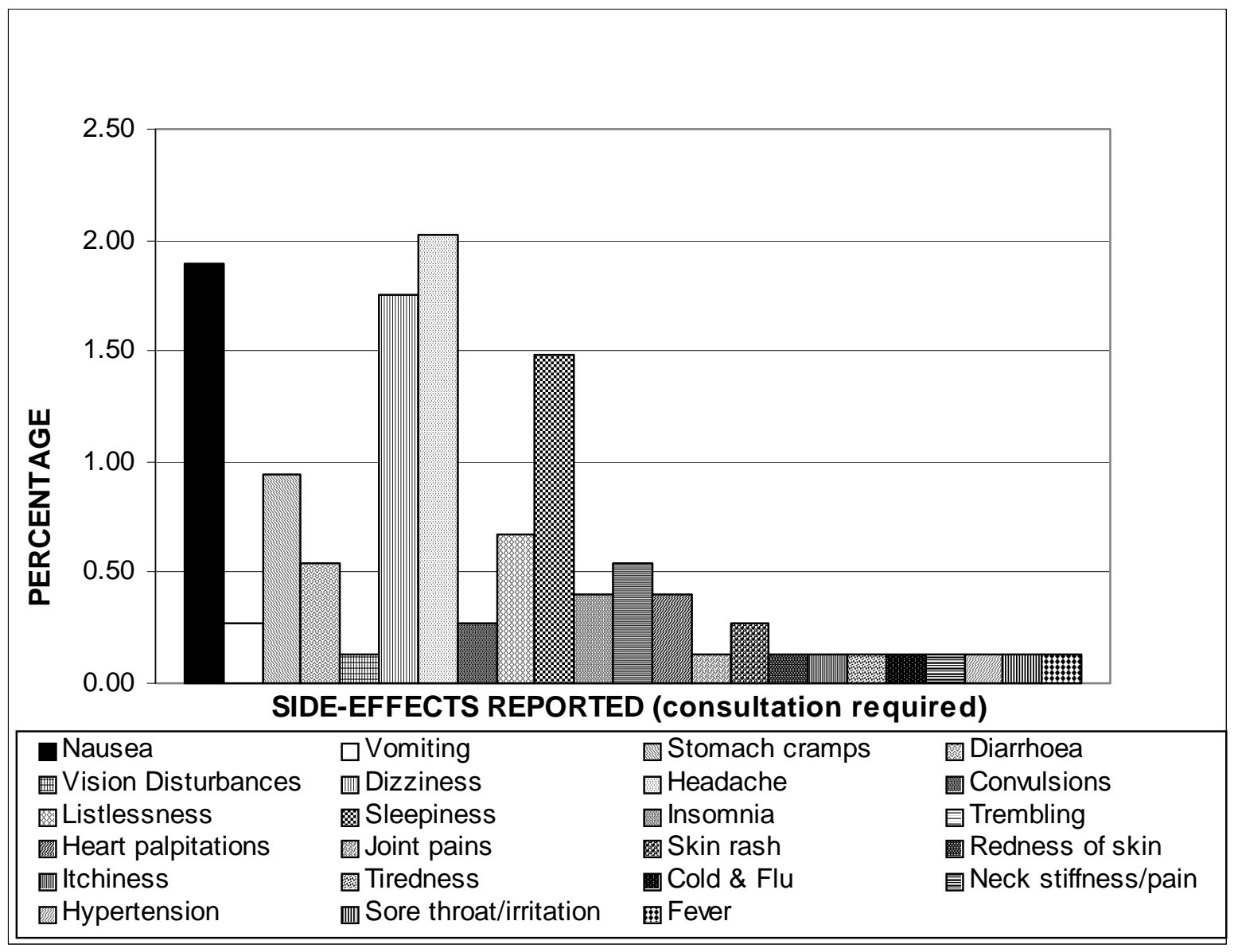

Figure 2: Percentage of the side-effects for which consultation was required (Single Dose) 
pants that only $51.4 \%(n=1443,94$ missing data $)$ of the participants took a single dose of ciprofloxacin $500 \mathrm{mg}$. The remaining $48,6 \%$ took more than one dose of ciprofloxacin $500 \mathrm{mg}$.

The total percentage of participants who reported sideeffects was $25.5 \%$ (392 participants) of the 1537 voluntary participants, but this included both the single dose and multiple dose groups. Side-effects resulting from multiple doses compared to side-effects resulting from a single dose did not indicate any practical significance. The side-effects reported by the single dose participants were $24.2 \%$ (expressed as a percentage of the total number of participants, 741 , on single dose only) and by the multiple dose participants $26.9 \%$ (expressed as a percentage of the total number of participants, 702 , multiple doses).

The participants requiring further medical consultation due to the severity of their side-effects after a single dose of ciprofloxacin $500 \mathrm{mg}$ totalled $5.4 \%$ (expressed as a percentage of 741 participants). When the effect size $(w)$ was calculated and compared to the guidelines as provided by Cohen (1988) no practically significant relationship was shown for any of the side-effects reported on single dose, multiple doses, nor when the effects of gender or requirement for medical consultation were tested.

\section{ACKNOWLEDGEMENTS}

All participants who were involved in this study are hereby thanked for their cooperation and input.

Professor Martie Lubbe provided valuable contributions and input concerning the compilation of the questionnaire, as well as expertise and assistance with the statistics programme, SAS.

M-Pharm students in Pharmacy Practice, Renier Coetzee, Jeanine Joubert (Student Council Representative-Academic Portfolio) and Juanita Plaath assisted with the distribution of questionnaires and entering information into the database.

Doctor Dorcas Rakumakoe and doctor Maria Letsie assisted with the translation of the questionnaire into Setswana.

\section{FUNDING}

The Department of Pharmacology (School of Pharmacy, PU for CHE) and the Department of Pharmacy Practice (School of Pharmacy, PU for CHE) contributed to the printing and photocopying costs during the investigation. The Department of Pharmacology (School of Pharmacy, PU for CHE) contributed towards the publication fees required.

\section{REFERENCES}

AMERICAN ACADEMY OF PEDIATRICS 2000: Meningococcal disease prevention and control strategies for practice-based physicians. Addendum: Recommendations for College Students. Pediatrics, 106(6): 1500-1504.

APICELLA, MA 1995: Neisseria meningitidis. (In: Mandell, GL; Bennett, JE \& Dolin, R eds. 1995: Principles and practice of infectious diseases; $4^{\text {th }}$ edition. New York: Wiley, pp 1896-1909).

BEERS, MH \& BERKOW, R 2003: The Merck Manual of diagnosis and therapy. Acute bacterial meningitis; $17^{\text {th }}$ edition. http:// www.merck.com/pubs/mmanual/ (date accessed: 01/10/2003). BURKE, P \& BURNE, SR 2000: Drug points: allergy associated with ciprofloxacin. British Medical Journal, 320(7236):679. http://www.bmj.bmjjournals.com/cgi/content/full/320/7236/679 (date accessed: 25/07/2003).

CANADA COMMUNICABLE DISEASE REPORT 1994: Guidelines for control of meningococcal disease. Canadian Medical Association Journal, 150:1825-1831.

CANADIAN PAEDIATRIC SOCIETY (CPS) AND INFECTIOUS DISEASE AND IMMUNIZATION COMMITTEE (IDIC) AND AMERICAN ACADEMY OF PEDIATRICS (AAP) AND COMMITTEE ON INFECTIOUS DISEASE (CID) 1997: Meningococcal disease prevention and control strategies for practice-based physicians. http:// www.cps.ca/english/statements/ID/id96-03.htm (date accessed: 25/07/2003).

CDC 2000: Refer to CENTERS FOR DISEASE CONTROL AND PREVENTION.

CENTRES FOR DISEASE CONTROLAND PREVENTION 2000: Meningococcal disease and college students. Morbidity and Mortality Weekly Report, 49:11-20. http://www.cdc.gov/mmwr/preview/mmwrhtml/rr4907a2.htm (date accessed: 25/07/2003). CHAMBERS, HF 2001: Antimicrobial agents: general considerations. (In: Hardman, JG; Limbard, LL \& Gilman, AG eds. 2001: Goodman and Gilman's. The pharmacological basis of therapeutics; $10^{\text {th }}$ edition. New York: McGraw-Hill; pp 1143-1170).

COHEN, J 1988: Statistical power analysis for the behavioural sciences; $2^{\text {nd }}$ edition. New Jersey: Lawrence Erlbaum.

CPS 1997: Refer to CANADIAN PAEDIATRIC SOCIETY. 
GAUNT, PN \& LAMBERT, BE 1988: Single dose ciprofloxacin for the eradication of pharyngeal carriage of Neisseria meningitidis. Journal of Antimicrobial Chemotherapy, 21(4):489-496. JOINT TASK TEAM FOR THE PROVINCIALAND LOCAL HEALTH AUTHORITIES AND THE PU FOR CHE 2003a: Nuutste oor breinvliesontsteking. Frikkie Kotze, media briefing. 30 July 2003. JOINT TASK TEAM FOR THE PROVINCIALAND LOCAL HEALTH AUTHORITIES, WHO AND THE PU FOR CHE 2003b: Meningitis at Potch. Frikkie Kotze, media briefing. 31 July 2003.

JOINT TASK TEAM FOR THE PROVINCIAL AND LOCAL HEALTH AUTHORITIES AND THE PU FOR CHE 2003c: Closure Report. Meningococcal meningitis outbreak in the Potchefstroom district. 12 August 2003. (Unpublished).

MASSACHUSETTS DEPARTMENT OF PUBLIC HEALTH 1999: Division of epidemiology and immunization: Meningococcal disease: Neisseria meningitidis. http://www.state.ma.us/dph/cdc/epii/ menin/nmenin.pdf (date accessed: 25/07/2003).

PETRI, WA2001: Antimicrobial agents: sulfonamides, trimethoprimsulfamethoxazole, quinolones and agents for urinary tract infections. (In: Hardman, JG; Limbard, LL \& Gilman, AG eds 2001: Goodman and Gilman's. The pharmacological basis of therapeutics; $10^{\text {th }}$ edition. New York: McGraw-Hill, pp 1171-1188).

POTCHEFSTROOM UNIVERSITY FOR CHRISTIAN HIGHER EDUCATION 2003: Frikkie Kotze, media briefing. 25 July 2003. http:// www.puk.ac.za/nuus/nuus303.html (date accessed: 25/08/2003). PU for CHE 2003: Refer to POTCHEFSTROOM UNIVERSITY FOR CHRISTIANHIGHEREDUCATION.

SAS Institute 2001: SAS for Windows. Version 8.2. 1999-2001. Cary, USA: SAS Institute.

STEYN, HS 2002: Practically significant relationships between two variables. SA Journal of Industrial Psychology, 28(3):1015.

WELSH MEDICINES INFORMATION CENTRE 2003: Questions and answers on meningitis. http://www.ukmi.nhs.uk/NewMaterial/html/ docs/19050301.pdf (date accessed: 25/08/2003).

WHO 1998: Control of epidemic meningococcal disease. WHO practical guidelines. http://www.who.int/emc-documents/meningitis/docs/whoemcbac983.pdf (date accessed: 25/08/2003).

\section{ADDENDUM: \\ VOLUNTARY QUESTIONNAIRE WITH REGARD TO THE MENINGITIDIS PREVENTATIVE PROJECT}

\section{Dear Staff member / Student}

In light of the current events the last couple of weeks concerning the meningitis outbreak in Potchefstroom, the pharmacologists and pharmacists of the School of Pharmacy of PU for CHE request your cooperation with the completion of the following questionnaire. The prophylactic medication used was ciprofloxacin $500 \mathrm{mg}$

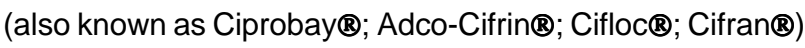
provided to you as a single dose on 28 July 2003 . Children would have received according to their age smaller doses of ciprofloxacin or even rifampicin as supplied by retail pharmacies; state hospitals or clinics. Ciprofloxacin is currently accepted worldwide as the most suitable oral drug for prophylaxis of Neisseria meningitidis in adults, despite several possible side effects as described in the pharmacological literature. We are of the opinion that you can assist us to obtain useful information regarding the actual side-effects of a single ciprofloxacin dose, as experienced by this specific target population. Information gained from the Potchefstroom experience may be valuable in future - not only for Potchefstroom residents, but also for the management of similar outbreaks in other communities. Your friendly and voluntary cooperation in completing this questionnaire is therefore much appreciated. All information will be treated confidentially.

Please mark the relevant space clearly with a cross $(x)$ and provide more detailed information only when requested. If a specific question is not relevant just ignore it. 
1. Participant:

\begin{tabular}{|c|l|l|}
\hline 1.1 & Personnel & \\
\hline 1.2 & Student, living OFF-CAMPUS & \\
\hline 1.3 & Student, living ON-CAMPUS in university residence & \\
\hline 1.4 & Other & \\
\hline
\end{tabular}

2. Age In years:

3. Gender:

4. If you are a female, are you

\begin{tabular}{|l|l|}
\hline & \\
\hline Female & Male \\
\hline
\end{tabular}

\begin{tabular}{|l|l|l|}
\hline 4.1 & Pregnant & \\
\hline 4.2 & Breast feeding & \\
\hline
\end{tabular}

5. Time (e.g. 17:00; 18:00; 20:15) of ingestion of the medication on 28 Julv 2003:

6. Where did you receive your medication from?

\begin{tabular}{|l|l|l|}
\hline 6.1 & PUK Campus & \\
\hline 6.2 & Potchefstroom Hospital & \\
\hline 6.3 & Municipal clinics & \\
\hline 6.4 & Retail pharmacies & \\
\hline 6.5 & Other & \\
\hline
\end{tabular}

\begin{tabular}{|l|l|l|l|}
\hline 7. & $\begin{array}{l}\text { Did you experience any side-effects or any strange reactions within 24 hours after } \\
\text { taking the medication, in other words any effects that you are not normally aware of? } \\
\text { (Please complete questions } 11-14 \text { even If your response here is NO.) }\end{array}$ & YES & NO \\
\hline
\end{tabular}

8. If you have responded YES to question 7, please mark $(x)$ which type of side-effect had been experienced in the column provided next to the relevant side-effect:

\begin{tabular}{|l|l|l|l|l|}
\hline 8.1 Nausea & & 8.7 Headache & 8.13 Heart palpitations & \\
\hline 8.2 Vomiting & & 8.8 Convulsions & 8.14 Joint pains & \\
\hline 8.3 Stomach cramps & 8.9 Listlessness & 8.15 Swollen joints & \\
\hline 8.4 Diarrhoea & & 8.10 Sleepiness & 8.16 Skin rash & 8.17 Redness of the skin \\
\hline 8.5 Visual disturbances & 8.11 Insomnia & & 8.18 Itchiness & \\
\hline 8.6 Dizziness & 8.12 Trembling & & 8 \\
\hline
\end{tabular}

9. List any other symptoms or side-effects that you have experienced within 24 hours of taking the medication. 


\begin{tabular}{|c|c|c|c|}
\hline & & YES & NO \\
\hline 10. & $\begin{array}{l}\text { Did you consult a doctor, pharmedist or nurse with regard to the side-effects you have } \\
\text { experienced? }\end{array}$ & & \\
\hline 11. & Are you currantly using any of the following chronle medication (on a regular daily basis): & & \\
\hline 11.1 & Thecphylline (eg Theoplus"; Uniphyl ; Theophen"; Euphyllin Retard ; Microphyllin ${ }^{6}$ ). & & \\
\hline 11.2 & 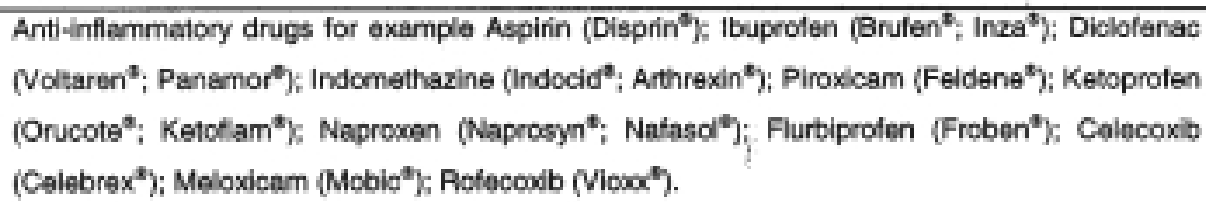 & & \\
\hline 11.3 & Warfarin & & \\
\hline 11.4 & Anti-epilaptic drugs (specify). & & \\
\hline 11.5 & Anti-diabetic drugs (specify). & & \\
\hline 11,6 & Ant-asthmatic drugs (specify). & & \\
\hline
\end{tabular}

12. List any other medication that you are currontly using on a regular daily basis that are not listed above.

\begin{tabular}{|l|l|l|l|}
\hline 13. & $\begin{array}{l}\text { Have you taken any prophylactic medication against meningitis, during the month of July 2003, } \\
\text { prior to this mass action that took place on } 28 \text { July 2003? }\end{array}$ & YES & NO \\
\hline
\end{tabular}

14. If you have responded YES, to question 13, please provide the following information if you can recall it.

\begin{tabular}{|l|l|l|}
\hline 14.1 & Date medication was used & \\
\hline 14.2 & Name of medication used & \\
\hline 14.3 & What was the dosago and quantity? & \\
\hline 14.4 & Place where you obtained the medication? & \\
\hline
\end{tabular}

Thenk you very much for your friendly cooparation in this investigation. We would appreciate it very much it you could deliwer the oomplated questionnaire to us before of on Wednesday 6 August 2003.

Personnel and students are requested to make use of the intem mail delivery system to:

Clprofloxacin Study, Department of Pharmacology, Bussilo 16. Alternativaly rotum it by e-mail or hand it to the designated student represontative of your residence.

Any inquiries regarding this questionnaire can be made to Michelle Viljoen (IkImw epuknet.ac.za) at 299-2232 or Rina Meyer (tolcim epuknet.ac.za) at 299-2228 or 018 299-2226. 